УДК 378.147.016:811.111

DOI: https://doi.org/10.35619/iiu.v0i9.11

Svitozara Bihunova

$\mathrm{PhD}$ in Psychology, Associate Professor, Associate Professor at Practice of the English Language Department,

Rivne State University of the Humanities,

Rivne, Ukraine

ORCID: 0000-0001-6860-6939

e-mail: svitozara.rv@gmail.com

Iryna Vorobiova

$\mathrm{PhD}$ in Pedagogy, Associate Professor, Associate Professor at Practice of the English Language Department, Rivne State University of the Humanities,

Rivne, Ukraine

ORCID: 0000-0002-7298-7575

e-mail:vorobyova.rdgu@gmail.com

\begin{abstract}
Alla Fridrikh
$\mathrm{PhD}$ in Pedagogy, Associate Professor, Associate Professor at Practice of the English Language Department, Rivne State University of the Humanities,

Rivne, Ukraine

ORCID: 0000-0001-9072-1845

e-mail: allafridrikh@gmail.com
\end{abstract}

\title{
PROJECT-BASED LEARNING AS A LIFE SKILL
}

\begin{abstract}
The article considers the features of the project-based learning as a mean of forming students' skills of independent work, critical thinking, problem solving, teamwork, etc. Project-based learning is a special method that helps students to acquire knowledge and skills through continuing work on a problem or issue that can be interesting and exciting, but at the same time challenging. The main feature of the projectbased learning is the presence of a specific educational goal, the focus on research, the authenticity of the problems studied in the project, and the emphasis on the importance of the work.

Planning of the project-based learning is a complex and time-consuming task as it includes both theoretical information and development of various handouts and additional materials of practical nature to be used in the process of work. For sure, they need clear instructions to be fully understandable for students. The teacher should think about making the students ready for each stage of the project, developing the key ideas of the project, clearing the standards of the project, developing connections with other subject areas, selecting the examples and tools for a feedback.

Engaging students in project-based learning effectively helps them to process the types of complex problems, to develop their ability to analyze, synthesize, evaluate, think critically and ask questions about the ideas to focus on.

Project-Based Learning effectively helps students to process the types of complex problems, to prepare students for being able to analyze, synthesize, evaluate, think
\end{abstract}


critically and ask questions about the ideas we need to focus on. Project-Based Learning prepares our students for the modern world and profound thinking, and deeper learning.

Project-Based Learning prepares students for academia, personal, and career success, and readies young people to face the challenges of their professional and personal lives, develop deep knowledge as well as critical thinking, creativity, and communication skills, unleash creative energy and cooperation among students and teachers. skills.

Key words: project, project-based learning, research, innovation, independent work

Formulation of the problem. Today we observe tectonic shifts in the understanding of Ukraine's place on the world's map. And it becomes obvious that there is a crucial necessity in preparing our youth to existing in such new and flexible circumstances. For quite a long period of time, traditional methodology was based on teaching foreign languages as a certain system in isolation from real communication. At present, educators realize that there is not just a need to teach four language skills (reading, speaking, listening, and writing) but to develop special communicative skills altogether with critical thinking and problem solving ones.

That is why taking an active part in "New Generation School Teacher", a joint project of the British Council Ukraine and the Ministry of Education and Science of Ukraine, will enable the students, future teachers, to learn how to teach effectively according to the European Profile for Language Teacher Education and due to this become well-prepared for the challenges of the 21st century.

Achieving new standards is the primary objective of the new Pre-Service Teacher Training (PRESETT) curriculum at Bachelor's level for trainee teachers of English. Rivne State University of the Humanities has been piloting the project and Baseline Study for three years. It is therefore recommended that University teachers take every opportunity to emphasize and foster modern ways of learning and teaching such as project-based and problem-solving learning. It is advised that university teachers make extensive use of modern approaches when planning and teaching their sessions.

It should be emphasized that the new Curriculum focuses on developing the professional skills of teaching through student active participation in the methodology course. Students can be engaged in active learning by using different methodological tools like project-based work - a purposeful, task-based activity through which students address authentic problems/questions and create some kind of product which they present at the end of the allocated time; it usually involves an extended amount of independent work, either by an individual student or by a group of students in and beyond the classroom (New Generation School Teacher).

So, Project-Based Learning prepares students for academia, personal, and career success, and readies young people to face the challenges of their professional and personal lives. Working on a project engages students in solving a real-world problem or answering a complex question. They are expected to demonstrate their knowledge and skills by developing a public product or presentation for a real audience. As a result, students develop deep knowledge as well as critical thinking, creativity, and communication skills. Besides, Project-Based Learning unleashes creative energy and cooperation among students and teachers.

Therefore, the aim of the paper is to study the key characteristics of ProjectBased Learning, the ways of its implementation into the curriculum, and the means 
of its planning and assessment. The tasks are to highlight the features of ProjectBased Learning and to identify structure, components, and essentials of ProjectBased Learning.

When using Project-Based Learning in the classroom, teachers act more as facilitators than directors, letting groups choose their own methods and develop their own ideas. In this way, the project becomes the main executor of the curriculum; in order to complete it, students employ principles from all subject areas, teaching themselves and learning as they go.

Presenting the main research material. First of all, we should distinguish the terms "projects" or "doing the projects" and "learning through projects" or "projectbased learning". To avoid misunderstanding, it is worth noting that they are not synonyms. The first term means that in doing the projects the project is the goal itself and is the climax of the work, while the latter term means the way or approach to learning. What is more, "doing the projects" is teacher-centred and "project-based learning" is student-centred.

We consider Project-Based learning as a special teaching method that helps students gain knowledge and skills by long-time work in order to investigate and analyze a problem or a question which can be interesting even breathtaking but difficult and complicated. Thus, students train through working on a continued project where "they complete an in-depth inquiry into a specific topic or question" (Smith A.). Such method is very helpful and convenient to be used in classroom. First of all, it makes it easy to cope with the class or group as students are really interested, motivated and orientated in finding out new materials themselves. Besides, this method involves using information and communication technologies (which are crucial for modern youth) and needs incorporation of data from multiple subject areas (which allows students to intensify their knowledge of other subjects).

Also we fully agree with Drew Perkins's point of view that the main difference between doing projects and Project-Based Learning lies in the sphere of inquiry and authenticity.

First of all, it is said that inquiry is one of the main and basic features of Project-Based Learning. To start the work it is proposed to use the Question Formulation Technique and then to proceed the inquiry the Driving Question will help (to make the process of thinking more visible with a continual revisiting of what students need to know and do) (Perkins).

The other keystone of this method is the focus on authenticity. Having asked students of their work purposes, we got the answers which varied from "it was my home task", "I need some good marks" to "my parents want me to study well". All the above does not tend to resonate with the majority of students because of authenticity lack. Implementation of Project-Based Learning demands clarification of the project's product, purpose and audience from both students and teachers. It means that every student should know what he/she is doing and what the reason is for it. Only in that case the project will be meaningful and successful.

It goes without saying that planning project-based learning is a complex and time-consuming task. It includes not just theoretical background but a thorough development of various hand-outs and additional materials students will need during their work. Besides, the teacher should prepare clear instructions to avoid misunderstanding.

In such a way, the teacher should think about: 
- preparing the students ready for each stage of the project (i.e. videos, articles etc.);

- $\quad$ working-out the key ideas of the project;

- clearing the standards each part of the project relates to;

- developing connections with other subject areas;

- selecting the examples;

- ways of completing each part of the project.

It should be mentioned that there are certain examples of tasks like posters, dioramas, PowerPoint presentations, etc. which are mistakenly thought to be projects.

As John Larmer and John R. Mergendoller emphasize, in order to get a meaningful project, two main criteria should be taken into consideration. One of them is to feel the importance of work to be done when the second criterion carries the educational purpose. Only the combination of these two criteria will lead to meaningful and successful project-based learning (Larmer, 2010).

Besides, the following seven essentials (which have been identified by J.Larmer and J.R.Mergendoller) are needed for a project to be considered Projectbased learning.

1. A Need to Know. The content of the project is focused on teaching students important skills and necessary knowledge. The task of the teacher as a facilitator to inspire students to gain knowledge and to apply skills in order to create project products. It is advised to start with one of these activities: a video, a discussion, a guest speaker, or a piece of mock correspondence that sets up a scenario. It is better not to distribute a packet of papers that may turn students off because it is alike a prelude to busywork.

2. A Driving Question. With the help of driving questions we reach the key idea, purpose, and objectives of the project. In order to link students to the core it is better to make questions provocative or open-ended and focused on solving a problem.

3. Student Voice and Choice. Students should be given the opportunity to make their choice about the products to be created and the designing style. We need to pay attention to time management Project-Based Learning experience. Students have opportunity to decide what products they will create, what resources they will use.

4. 21st Century Skills. A project develops the 21st century skills in students, in particular collaboration, communication, critical thinking, and the use of technology, which they need in the real life.

5. Inquiry and Innovation. Students conduct real inquiry, search for resources and the discovery of answers that lead to generating new questions, ideas, and their own conclusions; thus, it leads to innovation.

6. Feedback and Revision. It's crucial to give and to receive constructive feedback in order to make learning meaningful while creating high-quality products.

7. A Publicly Presented Product. Presentation of the product is not for the teacher or the mark. We think that a real audience is preferable. If done successfully, Project-Based Learning yields great results. In another case, it could be just a set of activities under the title "projects" but which are not rigorous Project-Based Learning (New Generation School Teacher).

So, we have highlighted the features of the effective Project-Based Learning as indication of leaning objectives that include knowledge and in-depth understanding of fundamental content standards, concepts, the competencies and the success skills 
(that are commonly called " 21 st Century Skills": critical thinking, problem solving, collaboration, and self-management). The next important feature is that a challenging problem or question makes learning more meaningful for students, because they need not only to gain knowledge, but to use it in solving a problem and answering the question. We consider Project-Based Learning inquiry an in-depth and even time-consuming process. Students are confronted with a challenging problem or question, ask questions, find resources to answer them, and then ask deeper questions until a satisfactory solution or answer is reached. Besides, a project should have an authentic context (e.g.: solving real life problems), involve the use of realworld processes, tasks and tools, and performance standards, have a real impact on others (e.g.: improving a community park), have personal authenticity (speaking to students' own interests, identities, and issues in their lives). Students should have input in a project, in particular: the questions they generate, the resources they use, the tasks and roles they take on, and the products they create, as well as use their judgment while solving a problem, answering a driving question. In order to improve Project-Based Learning, students and teacher should reflect through all the process on what they're learning, how they're learning, and why they're learning. Students should be taught how to give and receive constructive peer feedback with evidences that will improve project processes and products. The results of the Project-Based Learning have to be presented in a kind of a public product (e.g.: a presentation).

Conclusions and perspectives for further research. All the above mentioned will help us change the climate of the classrooms away from one where teachers and their students are often inherently in conflict (teacher: I want you to learn and do this student: I don't want to and you can't make me). It is very important to create a habit of mind where we're helping these students, teachers-to-be, to make better decisions, some of which can impact their entire lives. When we engage students in teaching and learning using Project-Based Learning, it effectively helps them to process the types of complex problems. We prepare students for being able to analyze, synthesize, evaluate, think critically and ask questions about the ideas we need to focus on. And we are fully convinced that using Project-Based Learning prepares our students for the modern world and profound thinking, and deeper learning.

\section{REFERENCES:}

Core Curriculum. English Language Teaching Methodology. Bachelor Level. New Generation School Teacher, [online] URL: https://ngschoolteacher.wixsite.com/ngscht/core-curriculum-1

Smith, A. Project-Based Learning. Performing in Education, LLC, [online] URL: https://performingineducation.com/project-based-learning

Perkins, D. 5 Characteristics of Project-Based Learning That Works [online] URL: https://wegrowteachers.com/5-characteristics-of-project-based-learning-that-works/

Larmer, J. \& Mergendoller, J. R. (2010) Seven Essentials for Project-Based Learning. Giving Students Meaningful Work. Vol.68, No 1. pp. 34-37. [online] URL: http://www.ascd.org/publications/educational_leadership/sept10/vol68/num01/Seven_Ess entials_for_Project-Based_Learning.aspx

\section{ПРОЕКТНА МЕТОДИКА ЯК ЗАСІБ ФОРМУВАННЯ ЖИТТЕВИХ НАВИЧОК}

Бігунова Світозара

кандидат психологічних наук, доцент, 
доцент кафедри практики англійської мови Рівненського державного гуманітарного університету,

м. Рівне, Україна

ORCID: 0000-0001-6860-6939

e-mail: svitozara.rv@gmail.com

Воробйова Ірина

кандидат педагогічних наук, доцент, доцент кафедри практики англійської мови

Рівненського державного гуманітарного університету,

м. Рівне, Україна

ORCID: 0000-0002-7298-7575

e-mail:vorobyova.rdgu@gmail.com

Фрідріх Алла

кандидат педагогічних наук, доцент, доцент кафедри практики англійської мови

Рівненського державного гуманітарного університету, м. Рівне, Україна

ORCID: 0000-0001-9072-1845

e-mail: allafridrikh@gmail.com

\begin{abstract}
Анотація. Стаття присвячена розгляду особливостей проектної методики як засобу формування в учнів навичок самостійної роботи, критичного мислення, розв'язання проблем, роботи в групі, тощо. Проектне навчання - це спеціальний метод, який допомагає студентам отримувати знання та навички за допомогою тривалої роботи над проблемою або питанням, яке може бути цікавим i захоплюючим, але водночас складним. Головна особливість проектної методики навчання полягає у наявності конкретної освітньої мети, спрямованості на дослідження, реальності проблем у проекті, акцентуванні на важливості виконуваної роботи.

Планування проектного навчання є складним і трудомістким завданням, оскільки включає в себе як теоретичну інформацію, так і розробку різноманітних роздаткових матеріалів практичного характеру для використання у процесі роботи. Проектне навчання потребує чітких інструкцій, які мають були зрозумілими для студентів. Викладач має спланувати навчальний процес так, щоб студенти були підготовлені до кожного етапу проекту, розробляючи ключові ідеї проекту, зважаючи на його стандарти та із врахуванням міжпредметних зв'язків і з вибіркою прикладів та інструментарію для конструктивного зворотного зв'язку.

У статті визначено сім основних складових розробки та застосування проектного навчання. Також розглянуто та висвітлено особливості ефективного проектного навчання як індикатору визначених освітніх цілей, які включають знання та глибоке розуміння фундаментальних стандартів змісту, концепцій, компетенцій та навичок успіху (які зазвичай називаються «Навички 21 століття»: критичне мислення, вирішення проблем, співпраця та самоврядування).

Залучення студентів до проектного навчання ефективно сприяє розв'язанню різнопланових проблем, розвиває здатність аналізувати, синтезувати, оцінювати, критично мислити і задавати питання щодо ідей, на яких варто зосередити свою увагу.
\end{abstract}

Ключові слова: проект, проектна методика навчання, дослідження, інновація, навички самостійної роботи.

Стаття надійшла до редакиії 12.02.2019 р. 